\title{
Role of Russia's Asian regions in the energy sector of the country: priorities and prospects for development in the first half of the 21st century
}

Anatoly Lagerev ${ }^{*}$, and Valentina Khanaeva, Melentiev Energy Systems Institute of Siberian Branch of the Russian Academy of Sciences, Irkutsk, Russia

\begin{abstract}
This paper shows the role of Russia's Asian regions in the production and consumption of energy resources for two scenarios (conservative and target) of the economy development in the country until 2035 and for the 2050 perspective. The dynamics and structure for the energy resources supply from the Asian regions to the European part of Russia and for export to the European and Asian countries is presented. The Asian regions are shown to still remain the main suppliers of energy resources in the country. By 2050 , about $80 \%$ of the energy resources produced in the Asian regions will be resupplied outside their borders, 56$57 \%$ of them for export.
\end{abstract}

\section{Introduction}

The Draft for the Energy Strategy of Russia [1] pays much attention to the Asian regions (Siberia, the Far East), whose development may provide an added momentum to the energy sector development in the country. The Draft notes that it is these regions, where a more dynamic growth in the energy consumption and production is expected, considering that the main prospects for increasing the export of Russian energy resources to the countries of Northeast Asia are related to them.

The energy sector development in Russia and its Asian regions in the long term will depend on a number of factors, such as the changes in: the economy development forecast and energy consumption levels in the country and its Asian regions; the domestic and export prices of energy resources; the terms and scale of constructing hydro power plants (HPPs), nuclear power plants (NPPs), non-traditional renewable energy sources (NRESs), etc.

Assessment of the impact of these factors on the energy sector development is rather a complicated task. The studies were carried out using the dynamic model (developed with participation of the authors) to optimize the territorial-production structure of the national energy sector [2]. The model describes the process of development of its territorialproduction structure up to 2050 with division into 5-year periods and separation of large macroregions and federal districts (FDs) in the territorial aspect.

\footnotetext{
* Corresponding author: lagerev@isem.irk.ru
} 
The model studies enabled us to form a balanced rational structure of regional energy sectors development for each of the Asian regions (West and East Siberia, the Far East) in dynamics, and to identify their role in the energy sector of the country.

The materials for the Draft of the Energy Strategy of Russia, as well as the authors' studies allowed a number of trends in the energy sector development in the country and its Asian regions until 2035, and for the 2050 perspective to be identified.

\section{Results of studies}

The paper presents two scenarios of the energy sector development in Russia and its Asian regions: conservative and target. Table 1 shows aggregated macroeconomic indicators of the economy development and the corresponding levels of energy consumption. The left boundary of the range of change in indicators corresponds to the conservative scenario, the right - to the target scenario.

Table 1. Forecast of economy development and energy consumption in Russia

\begin{tabular}{|c|c|c|c|c|}
\hline \multirow{2}{*}{ Indicators } & \multirow{2}{*}{2015} & \multicolumn{3}{|c|}{ Forecast } \\
\hline & & 2025 & 2035 & 2050 \\
\hline GDP*, $\$$ billion & 1555 & $1850-2105$ & $2300-2960$ & $3160-4610$ \\
\hline GDP growth rates relative to $2015, \%$ & 100 & $119-135$ & $148-190$ & 203-296 \\
\hline Mean annual GDP growth rates, \% & - & $1.6-2.9$ & $2.2-3.5$ & $2.1-3.0$ \\
\hline Population, million & 146 & 146 & $145-146$ & $145-147$ \\
\hline GDP per capita, $\$$ thousand/capita & 10.7 & $12-14$ & $16-20$ & $22-31$ \\
\hline $\begin{array}{l}\text { Domestic consumption of primary energy resources, } \\
\text { million tce }\end{array}$ & 966 & 1045-1107 & $1106-1192$ & $1160-1233$ \\
\hline $\begin{array}{l}\text { Mean annual growth rates of energy resources con- } \\
\text { sumption, \% }\end{array}$ & & $0.9-1.1$ & $0.6-0.7$ & $0.2-0.3$ \\
\hline GDP energy intensity, tce/ \$ 1000 & 0.62 & $0.56-0,53$ & $0.48-0.4$ & $0.37-0.27$ \\
\hline Energy intensity decline rates, relative to $2015, \%$ & 100 & $92-87$ & $79-66$ & $60-44$ \\
\hline
\end{tabular}

* in 2015 prices

Sources $[1,3,4]$ and authors' estimates

Table 2 provides the calculated dynamics of the change in demand of Russia and its Asian regions for energy resources which corresponds to the accepted scenarios of the economy development in the country.

Over the considered period, the consumption of energy resources in Russia may increase by $14-23 \%$ by 2035 , and by $20-28 \%$ by 2050 , thus reaching $1160-1235$ million tce. According to the forecasts, the energy consumption in the Asian regions will grow increasingly, and within the same period, may grow by $18-28 \%$ by 2035 , and by $28-38 \%$ by 2050 , thus reaching 360-385 million tce by 2050 .

At the same time, the consumption of oil products in the Asian regions may grow by $31-38 \%$, natural gas - by $40-48 \%$, coal - by $5-25 \%$, non-fuel energy resources (HPPs, NPPs, NRESs) by $47-59 \%$ over $2015-2050$.

Within the considered period, the structure of energy resources consumption in the Asian regions may change significantly: the gas share will increase from $35 \%$ in 2015 to $37-38 \%$, the coal share in consumption will decrease from $33 \%$ in 2015 to $27-30 \%$, and the consumption of non-fuel energy resources will increase by $2 \%$ (Fig. 1). 
Table 2. Forecasted dynamics of the demand for energy resources in Russia and its Asian regions***

\begin{tabular}{|l|c|c|c|c|}
\hline \multicolumn{1}{|c|}{ Indicators } & \multirow{2}{*}{2015} & \multicolumn{3}{c|}{ Forecast } \\
\cline { 3 - 5 } & & 2025 & 2035 & 2050 \\
\hline Russia, total, million tce/\% & $\frac{966}{100}$ & $\frac{1045-1107}{108-115}$ & $\frac{1106-1192}{114-123}$ & $\frac{1160-1233}{120-128}$ \\
Including: & & & & \\
Oil products, million t & 129 & $148-152$ & $160-163$ & $159-152$ \\
Natural gas, billion m ${ }^{3}$ & 454 & $487-527$ & $524-570$ & $548-566$ \\
Coal and others, million tce & 147 & $155-163$ & $150-164$ & $159-198$ \\
Non-fuel energy resources, million tce** & 116 & $125-127$ & $133-147$ & $151-175$ \\
\hline Asian regions, total, million tce/ \% & $\underline{280}$ & $\underline{306-321}$ & $\underline{330-358}$ & $\underline{358-386}$ \\
& 100 & $109-115$ & $118-128$ & $128-138$ \\
Including: & & & & \\
Oil products, million t & 39 & $44-45$ & $50-51$ & $54-51$ \\
Natural gas, billion m ${ }^{3}$ & 85 & $100-107$ & $110-119$ & $119-126$ \\
Coal and others, million tce & 93 & $88-93$ & $91-100$ & $97-116$ \\
Non-fuel energy resources, million tce** & 34 & $42-43$ & $44-50$ & $50-54$ \\
\hline
\end{tabular}

$* 2015=100 \%$

** HPPs, NPPs, NRES

***Asian regions: Siberia (including Tyumen Region) and the Far East

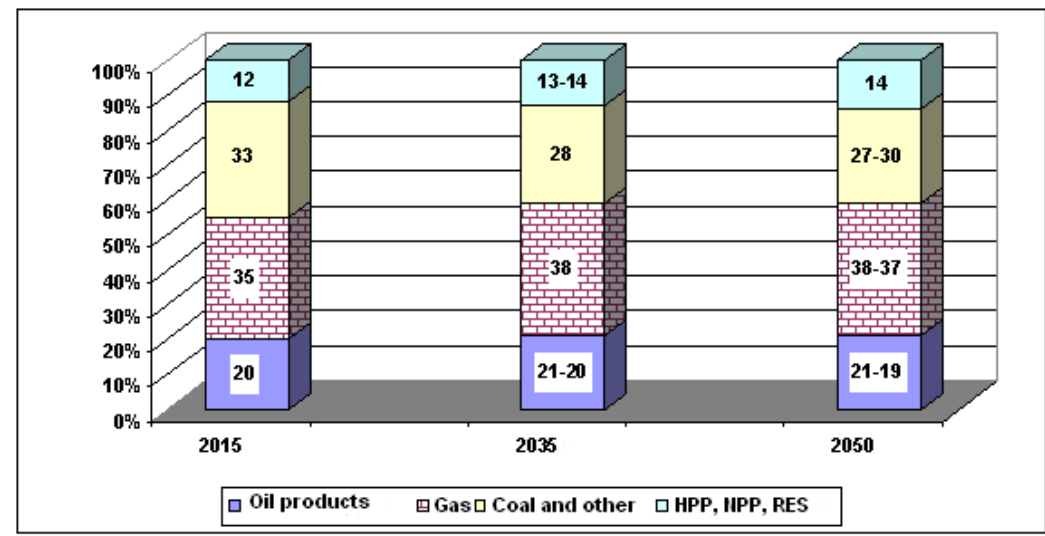

Fig.1. Structure of energy resources consumption in Russia's Asian regions (in tons of coal equivalent) NRES

At present, Russia has the status of the world's largest exporter of energy resources, whose volumes are a little lower (by 3\%) than their domestic consumption.

In the considered future, the export volumes and structure will be determined mainly by the economic expediency factors, and will depend not only on fuel prices in the world energy markets, but also on the prices and production volumes from Russian producers. Table 3 presents the dynamics (that is assumed in the calculations) of the world prices of energy resources. Table 4 demonstrates the dynamics of the domestic prices of gas and coal.

Table 5 shows the authors' forecasts for the export of Russian energy resources which were obtained based on the accepted world and domestic bid prices of energy resources.

It follows from the Table that over 20 years, the export of Russian resources may increase by $1-6 \%$ and by 2035 , it may be equal to $950-1000$ million tce with a further decrease to $865-960$ million tce (by $4-10 \%$ ) by 2050 . 
In the considered time horizon, the European vector of energy resources export will remain dominant for Russia (Fig. 2), but its share in the total export in the long term will decline: to $65-67 \%$ by 2035 , and to $61-63 \%$ by 2050 (versus $80 \%$ in 2015 ).

Table 3. Forecast of energy resource prices in the world markets*

\begin{tabular}{|l|c|c|c|c|}
\hline \multicolumn{1}{|c|}{ Indicators } & \multirow{2}{*}{2015} & \multicolumn{3}{c|}{ Forecast } \\
\cline { 3 - 5 } & & 2025 & 2035 & 2050 \\
\hline Oil, \$/barrel & 45 & $50-60$ & $50-65$ & $65-80$ \\
Natural gas, \$/1000 m ${ }^{3}$ & & & & \\
Europe & 240 & $250-270$ & $250-290$ & $300-350$ \\
Northeast Asia countries: & & & & \\
China (piped) & 250 & $275-290$ & $300-345$ & $330-380$ \\
Japan (LNG) & 310 & $340-30$ & $380-450$ & $430-500$ \\
Steam coal, \$/t & 63 & $60-70$ & $60-75$ & $60-80$ \\
\hline
\end{tabular}

*In 2015 prices.

Sources $[4,5]$ and the authors' estimates

Table 4. Forecast of bid fuel prices in Russia's markets*

\begin{tabular}{|c|c|c|c|c|}
\hline \multirow{2}{*}{ Indicators } & \multirow{2}{*}{2015} & \multicolumn{3}{|c|}{ Forecast } \\
\hline & & 2025 & 2035 & 2050 \\
\hline $\begin{array}{l}\text { European market } \\
\text { Natural gas, } \$ / 1000 \mathrm{~m}^{3} \\
\text { Steam coal, } \$ / \text { tce }\end{array}$ & $\begin{array}{c}90-105 \\
45-50\end{array}$ & $\begin{array}{c}120-130 \\
50-60\end{array}$ & $\begin{array}{c}120-150 \\
50-75\end{array}$ & $\begin{array}{c}125-185 \\
65-80\end{array}$ \\
\hline $\begin{array}{l}\text { Asian market } \\
\text { Natural gas, } \$ / 1000 \mathrm{~m}^{3} \\
\text { Steam coal, } \$ / \text { tce }\end{array}$ & $\begin{array}{c}95-100 \\
35-45\end{array}$ & $\begin{array}{c}120-135 \\
50-60\end{array}$ & $\begin{array}{c}145-170 \\
50-60\end{array}$ & $\begin{array}{c}170-200 \\
55-65\end{array}$ \\
\hline
\end{tabular}

* In 2015 prices.

Sources [6-9] and the authors' estimates

Table 5. Forecast of the export of energy resources from Russia

\begin{tabular}{|l|c|c|c|c|}
\hline \multicolumn{1}{|c|}{ Indicators } & \multirow{2}{*}{2015} & \multicolumn{3}{|c|}{ Forecast } \\
\cline { 3 - 5 } & & 2025 & 2035 & 2050 \\
\hline Export*, total, million tce & 940 & $945-1026$ & $950-1000$ & $865-960$ \\
\hline Including: & & & & \\
Oil and oil products, million t & 406 & $348-379$ & $316-338$ & $280-310$ \\
$\quad$ European vector & 324 & $246-272$ & $208-221$ & $180-190$ \\
Asian vector & 82 & $102-107$ & $108-117$ & $100-120$ \\
Natural gas, billion m ${ }^{3}$ & 200 & $268-291$ & $311-324$ & $295-340$ \\
European vector & 185 & $196-204$ & $221-226$ & $200-235$ \\
Asian vector & 15 & $72-87$ & $90-98$ & $95-105$ \\
Coal, million tce & 131 & $141-152$ & $146-149$ & $135-130$ \\
European vector & 76 & $82-78$ & $82-74$ & $75-60$ \\
Asian vector & 55 & $59-74$ & $64-75$ & $60-70$ \\
Electricity (balance), billion kWh & 13.5 & $21-23$ & $30-40$ & $70-80$ \\
Asian vector & 3.6 & $9-11$ & $20-30$ & $55-65$ \\
\hline Import, total, million tce & 38 & 37 & 19 & 1 \\
\hline Oil, million t & 2 & 4 & 1 & 1 \\
Natural gas, billion $\mathrm{m}^{3}$ & 22 & 20 & 16 & - \\
Coal, million tce & 10 & 10 & - & - \\
\hline
\end{tabular}

*Russian energy resources

At the same time, the availability of economically efficient energy resources in Russia's Asian regions, and the growing demand for them in the Asian-Pacific Region make the Asian export vector increasingly promising. According to the authors' estimates, in the considered period, the export of Russian energy resources in this vector may increase by 
factor of 1.7-2 and amount to 325-375 million tce. Herewith, the export of oil and oil products will increase by $22-46 \%$, natural gas - by factor of $6-7$, coal - by $10-30 \%$, electricity - by factor of 15-18 (Table 5).

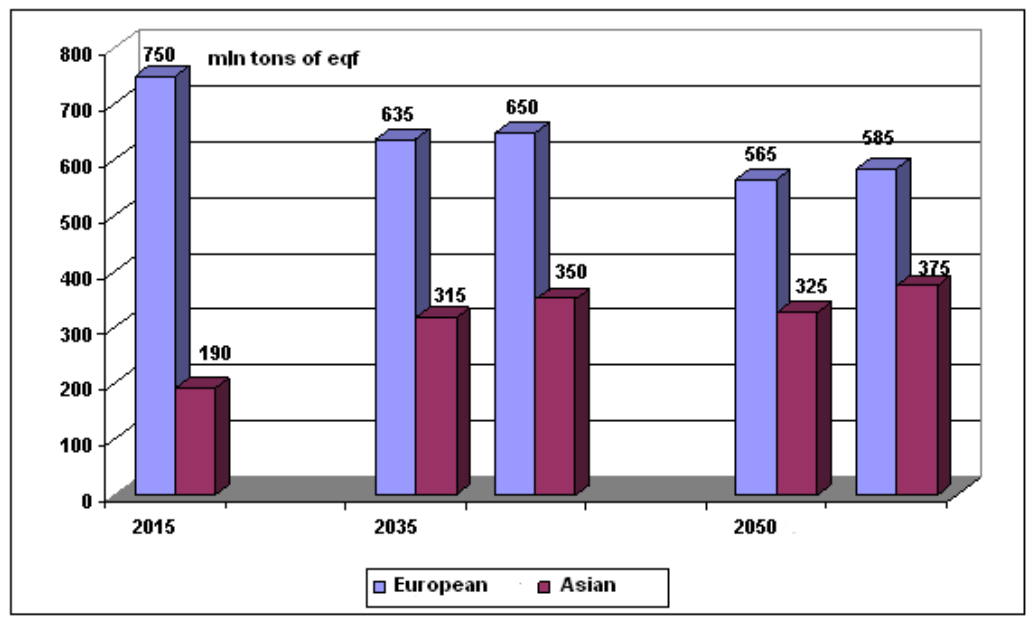

Fig. 2. Forecast of the export of Russian energy resources by vector, million tce

The calculated production of energy resources in Russia is presented in Table 6, and that in the Asian regions - in Table 7.

Table 6. Forecast of energy resources production in Russia

\begin{tabular}{|l|c|c|c|c|}
\hline \multicolumn{1}{|c|}{ Indicators } & \multirow{2}{*}{2015} & \multicolumn{3}{|c|}{ Forecast } \\
\cline { 3 - 5 } & & 2025 & 2035 & 2050 \\
\hline Production, total, million tce/\% & $\frac{1868}{100}$ & $\frac{1953-2096}{105-112}$ & $\frac{2038-2174}{109-116}$ & $\frac{2023-2192}{108-117}$ \\
\hline \multicolumn{1}{|c|}{ Including: } & & & & \\
Oil and gas condensate, million t & 533 & $496-530$ & $476-502$ & $445-465$ \\
Natural gas, billion m ${ }^{3}$ & 633 & $735-800$ & $819-878$ & $842-907$ \\
Coal, million t & 372 & $375-400$ & $390-420$ & $365-405$ \\
Other solid fuels, million tce & 11 & $15-16$ & $17-20$ & $22-26$ \\
Hydro energy, TWh & 170 & $209-210$ & $226-244$ & $276-295$ \\
Nuclear energy, TWh & 195 & $201-209$ & $233-265$ & $290-380$ \\
NRES, TWh & 2.4 & $9-10$ & $23-29$ & $54-55$ \\
\hline
\end{tabular}

$$
* 2015=100 \%
$$

The studies have showed that to meet the domestic demand for energy resources and their export, the production of energy resources in Russia should increase (as compared with 2015 ) by $8-17 \%$ by 2035 , and equal $2040-2175$ million tce, remaining at about this level until the considered period end (Table 6). In the calculations, the maximum possible production of energy resources in the country was assumed from the forecasts by the leading energy institutions and organizations of the country [1, 6-12].

The production of energy resources in the Asian regions should increase (as compared with 2015 ) by $14-22 \%$ by 2035 , and equal $1700-1825$ million tce, and decrease to $1635-$ 1760 million tce by 2050 (Table 7).

At the same time, the share of Asian resources in the country's total production of energy resources may increase up to $83-84 \%$ by 2035 (versus $80 \%$ in 2015 ), and then decrease to $80-81 \%$ by 2050 (Table 8 ). 
Siberia's share is expected to reach $66-68 \%$ of the oil produced in the country by 2050 , with the share of the Far East being 10-11\%.

Table 7. Forecast of the energy resources production in Russia's Asian regions

\begin{tabular}{|l|c|c|c|c|}
\hline \multirow{2}{*}{ Indicators } & \multirow{2}{*}{2015} & \multicolumn{3}{|c|}{ Forecast } \\
\cline { 3 - 5 } & & 2025 & 2035 & 2050 \\
\hline Production, total, million tce & 1496 & $1589-1730$ & $1700-1825$ & $1635-1760$ \\
Including: West Siberia* & 1250 & $1213-1308$ & $1260-1350$ & $1182-1263$ \\
East Siberia & 151 & $194-225$ & $235-260$ & $240-272$ \\
Far East & 95 & $182-197$ & $205-215$ & $213-225$ \\
\hline Of which: & & & & \\
\hline Oil, total, million t & 375 & $350-386$ & $345-378$ & $340-368$ \\
Including: West Siberia* & 312 & $263-293$ & $245-270$ & $238-258$ \\
$\quad$ East Siberia & 37 & $45-50$ & $55-60$ & $55-60$ \\
Far East & 26 & $42-45$ & $45-48$ & $47-50$ \\
\hline Natural gas, total, billion ${ }^{3}{ }^{3}$ & 587 & $685-750$ & $770-832$ & $732-787$ \\
Including: West Siberia* & 557 & $590-635$ & $650-700$ & $605-645$ \\
$\quad$ East Siberia & 8 & $35-45$ & $50-60$ & $55-65$ \\
Far East & 22 & $60-70$ & $70-72$ & $72-77$ \\
\hline Coal, total, million t & 352 & $352-377$ & $372-402$ & $354-394$ \\
Including: West Siberia & 216 & $200-210$ & $200-210$ & $185-200$ \\
East Siberia & 96 & $89-100$ & $106-116$ & $104-120$ \\
Far East & 40 & $63-67$ & $66-76$ & $65-74$ \\
\hline Hydro energy, billion kWh & 108 & $138-139$ & $152-170$ & $185-204$ \\
Including:Siberia & 93 & $114-115$ & $119-125$ & $133-143$ \\
Far East & 15 & 24 & $33-45$ & $52-61$ \\
\hline Nuclear energy, billion kWh & 0.2 & 0.8 & 0.8 & 0.8 \\
Including: Far East & 0.2 & 0.8 & $0,8$. & 0.8 \\
\hline NRES, billion kWh & 0.8 & $2.5-3$ & $8-10$ & 18 \\
Including:Siberia & 0.1 & $0.4-0,9$ & $3-5$ & 8 \\
Far East & 0.7 & 2.1 & 5 & 10 \\
\hline
\end{tabular}

* including Tyumen Region

Table 8. Share of the Asian regions in domestic total production of energy resources, $\%$

\begin{tabular}{|c|c|c|c|c|}
\hline \multirow{2}{*}{ Indicators } & \multirow{2}{*}{2015} & \multicolumn{3}{|c|}{ Forecast } \\
\cline { 3 - 5 } & & 2025 & 2035 & 2050 \\
\hline Energy resources, total & 80 & $81-82$ & $83-84$ & 80 \\
Including: Siberia & 75 & $72-73$ & $73-74$ & 70 \\
Far East & 5 & 9 & 10 & 10 \\
\hline Oil & 70 & $70-73$ & $72-75$ & $77-78$ \\
Including: Siberia & 65 & $62-64$ & $63-66$ & $66-68$ \\
Far East & 5 & $8-9$ & 9 & $11-10$ \\
\hline Natural gas & 92.5 & $93-94$ & $94-95$ & 87 \\
Including: Siberia & 89 & 85 & $85-87$ & 78 \\
Far East & 3.5 & $8-9$ & $9-8$ & 9 \\
\hline Coal & 95 & 94 & $95-96$ & 97 \\
Including: Siberia & 84 & 77 & 78 & 79 \\
Far East & 11 & 17 & $17-18$ & 18 \\
\hline Hydro energy & 64 & 66 & $67-70$ & $67-69$ \\
Including: Siberia & 55 & 55 & $52-51$ & $48-49$ \\
Far East & 9 & 11 & $15-19$ & $19-20$ \\
\hline
\end{tabular}


At present, the main oil production region is West Siberia. However, the oil production in West Siberia is forecasted to probably decrease by 40-65 million $\mathrm{t}(13-21 \%)$ by 2035 (relative to 2015), and by 55-75 million t (17-24\%) by 2050 .

Within the considered period, the oil fields in East Siberia and the Far East may contribute significantly to the domestic oil production, with a production increase of up to 60 million $t$ in East Siberia and up to 50 million $t$ in the Far East by 2035-2050.

By 2050 the share of the Asian regions in the country's gas production may decrease to $87 \%$ (versus $92.5 \%$ in 2015 ).

According to the forecasts, West Siberia will remain the country's main gas producing region in the studied time horizon. The gas production in West Siberia may grow from 555 billion $\mathrm{m} 3$ in 2015 to $650-700$ billion $\mathrm{m}^{3}$ by 2035 , and then decrease to $605-645$ billion $\mathrm{m}^{3}$ by 2050 . Amid the production decline in the Nadym-Pur-Taz Distrtict in West Siberia, the gas production will grow in Yamal, in the Ob-Taz Estuary, and in the Bolshekhetskaya Depression.

The promising regions for gas production in the country in the studied time horizon will be East Siberia (based on the development of the hydrocarbon fields in the Irkutsk Region and Krasnoyarsk Territory) and the Far East (based on the development of the gas condensate fields in the Sakha Republic (Yakutia), and the Sakhalin offshore fields). Under the favorable state of foreign markets in the Asian vector, the gas production in East Siberia may increase up to $60-65$ billion $\mathrm{m}^{3}$ by $2035-2050$ and up to $70-75$ billion $\mathrm{m}^{3}$ in the Far East. The coal production in West Siberia is forecasted to remain at 200-210 million $t$ until 2035 and then it will gradually decrease, reaching 185-200 million t by 2050 .

East Siberia and the Far East will provide the main growth in coal production. The coal production in East Siberia is forecasted to possibly grow by $8-25 \%$ by 2050 and by factor of 1.6-1.9 in the Far East. As a result, their share in the country's coal production will grow from $37 \%$ in 2015 to $46-48 \%$ by 2050 , and amount to $170-195$ million tce (of which $105-$ 120 million $\mathrm{t}$ in East Siberia and 65-75 million tce in the Far East).

In the considered time horizon, the Asian regions will remain the main suppliers of energy resources both to the domestic market and for export (Table 9).

In 2015 the Asian regions of Russia supplied 1218 million tce of energy resources (or $81 \%$ of their production), of which $44 \%$ were supplied to the European part of the country and 56\% for export. According to the authors' estimates, within 2015-2035 the supplies will grow, and by 2035 will reach $1380-1480$ million tce (growth by $13-22 \%$ ). In the subsequent period, the supplies will gradually decrease, and by 2050 will amount to12851390 million tce (78-79\% of production).

The share ratio will also change in the vectors of supplies (Table 9):

- the share of the energy resources supplies from Russia's Asian regions to its European part in the total supplies will decrease and by 2035 will make up $39-40 \%$ (versus $44 \%$ in 2015), and then by 2050 it will grow to $43-44 \%$. Within this period, the natural gas supplies to the European regions will increase by $70-80$ billion $\mathrm{m}^{3}$, and the oil and coal supplies will decrease (oil - by 10-20 million t, coal - by 8-24 million tce);

- the share of the energy resources export from the Asian regions of Russia in the European vector in the total export will decrease from $40 \%$ in 2015 to $35-37 \%$ by 2035 , and to $30-31 \%$ by 2050 . At the same time, within the considered period the export of West Siberian oil will reduce by $45-50$ million $t$, and the export of West Siberian gas and Kuznetsk coal will increase by 2035 , and then by 2050 will decrease;

- the share of the energy resource export from Russia's Asian regions in the Asian vector (APR countries) will increase from $16 \%$ in 2015 to $24-25 \%$ by 2035 , and to $25-27 \%$ by 2050 . In this period, the export of oil and oil products will grow from 80 million $t$ to 100-120 million $t$, the export of natural gas - from 15 to $95-105$ billion $\mathrm{m}^{3}$, the export of coal - from 55 to $60-70$ million tce. 
Table 9. Export of energy resources from Russia's Asian regions

\begin{tabular}{|c|c|c|c|c|}
\hline \multirow{2}{*}{ Energy resources } & \multirow{2}{*}{2015} & \multicolumn{3}{|c|}{ Forecast } \\
\hline & & 2025 & 2035 & 2050 \\
\hline Supplies, total, million tce/\% & $\frac{1218}{100}$ & $\frac{1284-1415}{100}$ & $\frac{1380-1480}{100}$ & $\frac{1285-1390}{100}$ \\
\hline \multicolumn{5}{|l|}{ Including: } \\
\hline $\begin{array}{l}\text { - to Russia's European part, } \\
\text { million tce/\% } \\
\text { of which: }\end{array}$ & $\frac{534}{44}$ & $\frac{500-555}{39}$ & $\frac{540-595}{39-40}$ & $\frac{560-600}{44-43}$ \\
\hline oil, million t & 81 & $57-66$ & $57-62$ & $60-70$ \\
\hline natural gas, billion $\mathrm{m}^{3}$ & 323 & $335-370$ & $368-405$ & $395-405$ \\
\hline coal, million tce & 50 & $37-39$ & $40-44$ & $26-42$ \\
\hline $\begin{array}{l}\text { - for export, total, million tce } \\
\text { including: }\end{array}$ & 684 & $784-860$ & $840-885$ & $725-790$ \\
\hline European vector, & $\underline{493}$ & $\underline{493-532}$ & $\underline{515-525}$ & $\underline{400-415}$ \\
\hline $\begin{array}{l}\text { million tce/\% } \\
\text { of which: }\end{array}$ & 40 & 38 & $37-35$ & $31-30$ \\
\hline oil, million $\mathrm{t}$ & 176 & $150-170$ & $140-150$ & $125-130$ \\
\hline natural gas, billion $\mathrm{m}^{3}$ & 165 & $177-185$ & $205-210$ & $125-150$ \\
\hline coal, million tce & 54 & $80-76$ & $80-70$ & $75-60$ \\
\hline Asian vector, & $\underline{191}$ & $\underline{291-328}$ & $\underline{325-360}$ & $\underline{325-375}$ \\
\hline $\begin{array}{l}\text { million tce/\% } \\
\text { of which: }\end{array}$ & 16 & 23 & $24-25$ & 25-27 \\
\hline oil and oil products, million $\mathrm{t}$ & 82 & $102-107$ & $108-117$ & $100-120$ \\
\hline natural gas, billion $\mathrm{m}^{3}$ & 15 & $72-86$ & $90-98$ & $95-105$ \\
\hline coal, million tce & 55 & $59-74$ & $64-75$ & $62-70$ \\
\hline electricity, billion $\mathrm{kWh}$ & 4 & $9-11$ & $20-30$ & $55-65$ \\
\hline
\end{tabular}

\section{Conclusions}

The conclusions based on the conducted studies are as follows:

1. According to the authors' forecasts for the considered time horizon (2015-2050), the energy resources consumption in the country may increase by $20-28 \%$, while the energy resources consumption in the country's Asian regions will grow by $28-38 \%$. As a result, the share of the Eastern regions in the total consumption of energy resources in the country will increase from $29 \%$ in 2015 to $31-32 \%$ by 2050 .

2. For the studied period the Asian regions will remain the main suppliers of energy resources both to the domestic market and for export.

In 2015, Russia's Asian regions supplied 1218 million tce of energy resources (or $81 \%$ of their total production), of which $44 \%$ were supplied to the European part of the country, and 56\% - from. According to the forecasts, within 2015-2035, the supplies will grow by $13-22 \%$, but then it will decline and by 2050 will equal $1285-1390$ million tce.

3. The share ratio in the vectors of supplies will also change.

- the share of the energy resources supplies from the Asian regions of the country to its European part by 2035 in the total supplies will decrease to $39-40 \%$ (versus $44 \%$ in 2015), and then, by 2050 , will grow to $43-44 \%$;

- the share of the energy resources export of Russia's Asian regions in the European vector will decrease from $40 \%$ in 2015 to $35-37 \%$ in 2035 , and to $30-31 \%$ by 2050 . 
- the share of the energy resources export in the Asian vector will increase from $16 \%$ in 2015 to $24-25 \%$ by 2035 , and to $25-27 \%$ by 2050 .

4. According to the authors' estimates, despite the absolute growth in the export of oil (oil products) and coal, their share in the structure of energy resources export in the Asian vector will decrease: from $61 \%$ in 2015 to $44-45 \%$ of oil, from $29 \%$ to $19 \%$ of coal by 2050 .

At the same time, the share of gas in the structure of energy resources export will grow from $9 \%$ in 2015 to $32-33 \%$ by 2050 .

5. To meet the domestic demand for energy resources and their export, the energy resources production in Russia's Asian regions should grow by $14-22 \%$ by 2035 (versus 2015), and equal 1700-1825 million tce, and then, by 2050, it should decrease by $3.5-4 \%$. By 2050 , the share of the Asian regions are expected to reach $76-79 \%$ of the produced oil in the country, $87 \%$ of the produced natural gas, $97 \%$ of the produced coal, and $67-69 \%$ of the electricity produced by HPPs.

\section{Acknowledgements}

The study was conducted under Scientific Project XI.174.2.2 of the Program for Basic Researches from the Siberian Branch of the Russian Academy of Sciences, Reg. No. AAAAA17-117030310435-0

\section{References}

1. Draft of the Energy Strategy of the Russian Federation for the period up to 2035 (edited as of February 1, 2017). - 77 p. [online]. Available at: https://minenergo.gov.ru/node/1920 (Accessed date: June 2018)

2. Methods and models for forecast studies of the energy-economy interrelations/Yu.D. Kononov, E.V. Galperova, D.Yu. Kononov, A.V. Lagerev, O.V. Mazurova, V.N. Tyrtyshny. Novosibirsk: Nauka, 178 p. (2009)

3. Forecast of socio-economic development of the Russian Federation for 2017, and for the planning period of 2018-2019. M., 2016.- 446 p. [online]. Available at: http://economy.gov.ru/minec/activity/sections/macro/2016241101 (Accessed date: June 2017 June)

4. Forecast of energy development in the world and in Russia 2016 / Ed. by A.A., Makarov, L.M. Grigoriev, T.A. Mitrova; ERI RAS - AC under the Government of RF. M., 2016, 200 p. [online]. Available at: https://www.eriras.ru/files/forecast_2016_rus.pdf(Accessed date: March 2017)

5. World Energy Outlook 2015. Paris, France. International Energy Agency (IEA). 545 p. (2015)

6. Energy sector of Russia - 2015. Issue - June, 2016. Analytical Center under the Government of RF [online]. Available at: http://ac.gov.ru/files/publication/a/9162.pdf (Accessed date: July 2017).

7. Presentation of the Ministry of Energy of Russia "Outcomes of the work of the Ministry of Energy of Russia and the main results of the energy sector operation in 2016. Tasks for the mid-term perspective." M., 2017. [online]. Available at: https: //minenergo.gov.ru/node/7687 (Accessed date: June 2017).

8. Annual report of PJSC Gazprom for 2016. M., 2017, 208 p. [online]. Available at: http://www.gazprom.ru/f/posts/36/607118/gazprom-annual-report-2016-en.pdf (Accessed date: July 2017). 
9. Oil and gas complex of Russia - 2017. Part 1. Oil industry -2017: long-term trends and the current state // L.V. Eder, I.V. Filimonova, V.Yu. Nemov et al. / Ed. by A.E. Kontorovich. Novosibirsk: IPGG SB RAS, 2018, 86 p. [online]. Available at: http://www.ipgg.sbras.ru/en/files/orgunits/energyreport/petroleum-industry-russia2017.pdf (Accessed date: May 2018).

10. B.G. Saneev, A.V. Lagerev, V.N. Khanaeva. Development of the Russian gas market in the long-term perspective: the role of the Asian regions. Gazovaya promyshlennost, No. 8, pp. 14-18 (2015)

11. Long-term program for the coal industry development in Russia for the period until 2030. Approved by the Government of RF as of 21.01.2012, No. 14-r. [online]. Available at: https://www.rosugol.ru/upload/pdf/dpup_2030.pdf (Accessed date: April 2016).

12. L.S. Plakitkina, Yu.A. Plakitkin. New scenarios of the Russian economy development: actualized forecasts of coal production development. Ugol' (Coal), No. 5, pp. 66-72 (2018) 